\title{
Analisis Kinerja Strategi Bisnis Koperasi Karyawan UNTAG Surabaya dengan Pendekatan Balance Scorecard
}

\author{
Mochammad Singgih \\ Universitas 17 Agustus 1945 Surabaya \\ Djoko Sulistyono \\ Universitas 17 Agustus 1945 Surabaya \\ muhammad1singh@gmail.com
}

\begin{abstract}
Abstrak
Koperasi adalah penggerak ekonomi rakyat, yang dipandang sebagai soko guru perekonomian diharapkan tetap mampu bertahan ditengah perkembangan jaman yang erat akan persaingan bisnis. Koperasi dituntut dapat tetap menjalankan usahanya dengan terus meningkatkan kinerja dalam pengorganisasiannya agar dapat mencapai tujuan yang diharapkan. Kaplan dan Norton dalam bukunya balanced scorecard menjelaskan Organisasi perlu memperhatikan perpektif lain yang tidak kalah penting selain keuangan yakni pelanggan, proses bisnis internal, dan pertumbuhan/pembelajaran. Rumusan masalah yang diangkat dalam penelitian ini yakni: 1 . Bagaimana kinerja KopKar Untag Sby melalui pendekatan Balanced Scorecard pada tahun 2020 ? dan 2. Apa langkah-langkah strategis bagi KopKar Untag Sby dalam memperbaiki dan meningkatkan kinerja di masa akan datang ?

Komponen-komponen Balanced scorecard diuraikan lebih lanjut dalam analisis deskriptif. Temuan dari penelitian dapat diuraikan sebagai berikut: Tiga parameter perspektif keuangan semua mengalami peningkatan dan penurunan selama 5 tahun ( 2015 -2019) yakni Net Profit Margin (NPM), Return On Asset ( ROA ) dan Return On Equity (ROE). Dalam perspektif pelanggan 2 variabel kurang baik yakni : Customer retention $\mathrm{dan} \mathrm{Cust}$ o mer Acquis it io n naik turun. Kepuasan anggota sangat baik. Dan Jumlah keluhan cenderung menurun. Hal ini menunjukkan kecenderungan yang baik. Namun untuk kinerja Proses Bisnis Internal, Inovasi dinilai kurang. Tiga parameter perspektif pertumbuhan dan pembelajaran yakni Karyawan, Pengurus dan Pengawas menunjukkan relative baik. Jadi secara keseluruhan kinerja KopKar Untag Sby ditinjau dari 4 perspektif Balanced Scorecard hanya 1 persepektif proses bisnis internal (Inovasi) yang kurang. Sehingga secara umum kinerja KopKar Untag Sby masih dalam kategori baik.
\end{abstract}

Kata kunci: Pengukuran kinerja, Balanced Scorecard, Koperasi, Penggerak Ekonomi Rakyat.

\section{Pendahuluan.}

Konsep Balanced Scorecard dikembangkan sebagai konsep pengukuran kinerja organisasi lebih dari dua decade oleh Kaplan \& Norton (Kaplan \& Norton, 1992). Penerapan konsep Balanced Scorecard telah diadopsi oleh banyak perusahaan bahkan organisasi pemerintah sebagaimana yang telah dikemukakan oleh Butler, Letza dan Neale (Butler, Letza dan Neale, 1997) dimana beberapa organisasi besar yang ada di Amerika Serikat seperti United States Government, Intel, Apple, Miliken. Seiring dengan perkembangan jaman metode Balanced Scorecard tidak hanya digunakan sebagai alat pengukuran kinerja bagi lingkup bisnis (Nirlaba) namun juga berfungsi sebagai alat untuk mengukur kinerja organisasi pemerintah dan organisasi non nirlaba lainnya. 
Tiga pilar ekonomi nasional yaitu Badan Usaha Milik Negara (BUMN), Swasta dan koperasi berupaya melakukan usaha diberbagai sector, diantaranya seperti sektor jasa keuangan maupun pembiayaan. Badan usaha tersebut memberikan berbagai jasa keuangan maupun pembiayaan untuk membantu serta memfasilitasi masyarakat dan sektor Usaha Mikro, Kecil dan Menengah (UMKM).

Koperasi merupakan suatu badan usaha berasaskan kekeluargaan yang bertujuan untuk menyejahterakan anggotanya seperti yang tercantum dalam Undang-Undang No. 25 Tahun 1992 tentang Perkoperasian. Koperasi yang dipandang sebagai soko guru perekonomian diharapkan tetap mampu bertahan ditengah perkembangan jaman yang erat akan persaingan bisnis. Koperasi dituntut untuk dapat tetap menjalankan usahanya dengan terus meningkatkan kinerja dalam pengorganisasiannya agar dapat mencapai tujuan yang diharapkan. Untuk mengukur hasil kinerja dibutuhkan suatu pengukuran kinerja. Pengukuran kinerja penting dilakukan untuk menilai kinerja yang telah dilakukan organisasi tersebut serta dapat mengevaluasi aktivitas yang telah dilakukan.

Kinerja suatu organisasi tidak lagi diukur dari segi keuangan, namun juga memperhatikan aspek lain dari segi non keuangan pula sehingga antara aspek keuangan dan non keuangan terdapat keseimbangan. Metode yang digunakan untuk mengukur kinerja baik dari aspek keuangan maupun non keuangan adalah dengan menggunakan metode Balanced Scorecard.

Oleh sebab itu, pengukuran kinerja dari segi non keuangan perlu dilakukan agar perusahaan / koperasi tidak hanya berfokus pada peningkatan dan perbaikan di aspek keuangan saja, tetapi juga memperhatikan aspek non keuangan.

Dari uraian diatas maka dilakukan penelitian: "Analisis Kinerja Strategi Bisnis Koperasi Karyawan Untag Sby dengan pendekatan metode Balanced Scorecard" di Koperasi Karyawan Untag Surabaya. Dengan tujuan untuk : Menganalisis kinerja KopKar Untag Sby pada tahun 2019 / 2020 dengan pendekatan Balanced Scorecard, dan Merekomendasikan langkahlangkah strategis bagi KopKar Untag Sby dalam memperbaiki dan meningkatkan kinerja di masa datang.

\section{Landasan Teori.}

\section{Pengukuran Kinerja Pada Koperasi}

Menurut Partomo (Partomo dan Soedjono 2009) bahwa koperasi juga memiliki kekhususan yang berbeda dengan non koperasi untuk menjadi karakteristik yang membedakan. Kekhususan dari koperasi adalah bahwa setiap fungsi manajemen harus se lalu memperhatikan manfaat bagi anggota koperasi selaku pemilik dan sekaligus pe la ng g a yang berbeda dari non koperasi yang tidak mempengaruhi identitas ganda dari pemiliknya.

Kekhususan yang dimiliki koperasi menyebabkan ada perhatian dalam pengembangan guna mencapai tujuan yang diharapkan yaitu meningkatkan kesejahteraan anggota. Pengelola koperasi hendaknya berupaya dengan seksama untuk mengembangkan koperasi, sehingga pada akhimya tujuan yang diharapkan dapat dicapai. Perbaikan terhadap kelemahan hendaknya dilakukan secara berkelanjutan agar tujuan yang diharapkan dapat dicapai. Perbaikan akan dapat dilakukan pengelola koperasi bila mampu melakukan pengukuran kinerja dengan baik. 
Pengukuran kinerja akan mendatangkan manfaat bagi pengelola koperasi untuk mengetahui posisi kemampuan yang dimiliki dalam berusaha, sehingga dengan demikian akan menjadi informasi yang sangat berarti dalam rangka melakukan perbaikan sebagai proses penyempurnan yang pada akhimya mampu menghantarkan koperasi mencapai tujuan meningkatkan kesejahteraan anggota.

Pengukuran kinerja pada koperasi sama seperti badan usaha yang lain hendaknya ditinjau dari sisi keuangan dan non keuangan. Adanya pengukuran kinerja non keuangan mendatangkan kemampuan melakukan operasional koperasi yang efesien dan efektitif dengan berdasar informasi kinerja non keuangan.

Kemampuan menciptakan operasional koperasi yang efisien dan efektif akan mendatangkan kemampuan menciptakan kinerja keuangan yang baik untuk menjadi modal dalam rangka meningkatkan kesejahteraan anggota.

\section{Keunggulan Balanced Scorecard}

Menurut Halim (Abdul Halim 2009) keunggulan Balanced scorecard adalah:

1) Merupakan konsep pengukuran yang komprehensif yang menekankan pengukuran kinerja manajemen tidak hanya pada aspek kuantitatif saja tetapi juga aspek kualitatif.

2) Merupakan konsep yang adaptif dan responsive terhadap lingkungan bisnis.

3) Memberikan fokus terhadap tujuan menyeluruh perusahaan.

\section{Balanced Scorecard untuk Pengukuran Kinerja Koperasi}

Dari pernyataan Vincent Gaspers (Gaspers, 2003) bahwa balanced scorecard merupakan suatu konsep manajeme n yang membantu menerjemahkan strategi ke dalam tindakan. Balanced scorecard lebih dari sekedar sistem pengukuran operasional atau teknis. Penggunaan balanced scorecard yang inovatif berperan penting sebagai suatu sistem manajemen strategis yang mengelola strategi sepanjang waktu.

Kemampuan meningkatkan kinerja yang dimiliki akan mendorong koperasi untuk lebih maju, menarik anggota yang lebih banyak, serta akhimya mampu mencapai tujuan yang lebih umum yaitu membantu meningkatkan perekonomian nasional disamping meningkatkan kesejahteraan anggota.

Penerapan balanced scorecard akan berhasil bila seluruh bagian di perusahaan memiliki komitmen melakukan dengan baik sesuai dengan perspektif yang dibutuhkan. Hal ini disebabkan balanced scorecard melakukan tinjauan kinerja dari perspektif keuangan dan non keuangan yang terdiri dari pelanggan, proses bisnis internal, serta pembelajaran dan pertumbuhan.

\section{Perspektif Balanced Scorecard dalam Pengukuran Kinerja Koperasi}

Perspektif Balanced Scorecard, menurut Sujarweni (Sujarweni.V.W, 2015) :

\section{Perspektif Keuangan}

BSC memakai tolak ukur untuk melakukan penilaian terhadap kinerja keuangan menggunakan rasio-rasio keuangan seperti laba bersih dan ROI. Rasio tersebut sering 
digunakan perusahaan untuk menilai kemampuan perusahaan untuk menghasilkan laba.

2. Perspektif Pelanggan

Perspektif pelanggan adalah perspektif yang mengevaluasi dan mengukur kinerja yang berorientasi pada pelanggan sampai dimana tingkat kepuasan yang mereka peroleh. Ada 3 hal yang digunakan sebagai bahan penilaian pelanggan yaitu tingkat kepuasan konsumen, penguasaan pangsa pasar perusahaan, dan profitabilitas konsumen. lni digunakan untuk mengukur seberapa besar keuntungan yang berhasil dicapai oleh perusahaan.

3. Perspektif Proses Bisnis lnternal

Perspektif proses bisnis internal adalah perspektif yang mengevaluasi relevansi perancangan sistem penilaian kinerja perusahaan yang mampu mengimplementasikan strategi perusahaan dan membentuk suatu mekanisme proses bisnis internal yang baik. Tahapan dalam proses bisnis internal meliputi: proses inovasi, proses operasi, dan proses penyampaian produk atau jasa kepada pelanggan.

4. Perspektif Pertumbuhan dan Pembelajaran

Perspektif pertumbuhan dan pembelajaran adalah perspektif yang menilai ukuran kinerja yang dapat mengarahkan perusahaan untuk melakukan perubahan agar dapat tetap berkembang dan menciptakan masa depan. Adapun faktor-faktor yang harus diperhatikan yaitu Kemampuan karyawan, Kemampuan sistem informasi, dan Motivasi, Pemberian dan Pembatasan Wewenang.

\section{Metode Penelitian.}

\section{Tempat dan Waktu Penelitian}

1. Tempat Penelitian Penelitian ini dilakukan di KopKar Untag Sby yang terletak di dalam Kampus Untag Sby, Jalan Semolowaru 45 Surabaya.

2. Waktu Penelitian

Penelitian dilakukan pada bulan Juni 2020 - Nopember 2020.

\section{Subyek dan Objek Penelitian}

1. Subyek Penelitian

Subjek penelitian adalah orang - orang atau pihak - pihak yang akan dijadikan sasaran penelitian untuk memperoleh data yang diinginkan. Dalam penelitian ini, subjek penelitian terd iri dari:
a. Anggota Koperasi
b. Karyawan Koperasi
c. Pengurus Koperasi
d. Pengawas Koperasi

2. Obyek Penelitian

a. Laporan Keuangan KopKar Untag Sby periode 2015-2019.

b. Hasil wawancara dengan pengurus dan karyawan yang akan digunakan sebagai data dalam perspektif pertumbuhan dan pembelajaran serta gambaran umum KopKar Untag 
Sby.

c. Hasil kuesioner anggota, pengurus, dan karyawan serta pengawas koperasi yang digunakan untuk mengetahui tingkat kepuasan anggota pada perspektif pelanggan dan kepuasan pengurus, pengawas serta karyawan pada perspektif pertumbuhan dan pembelajaran.

\section{Teknik Analisis Data}

Langkah Langkah Analisa data adalah sbb :

a), Pengumpulan data meliputi : Laporan Keuangan dan jumlah anggota KopKar Untag Sby tahun 2015-2019; hasil kuesioner anggota, karyawan, pengurus dan pengawas; Dan hasil wawancara dengan pengurus.

b). Mengukur kinerja koperasi berdasarkan perspektif pada Balanced Scorecard

\section{Perspektif Keuangan}

Berdasarkan data laporan keuangan KopKar Untag Sby diperiode 2015-2019 dianalisis menggunakan rasio-rasio berikut:

\section{a) Net Profit Margin (NPM):}

Net Profit Margin digunakan untuk mengukur tingkat laba yang diperoleh koperasi atas setiap pendapatan yang diperoleh. Semakin tinggi rasio NPM berarti kinerja koperasi semakin efisien.

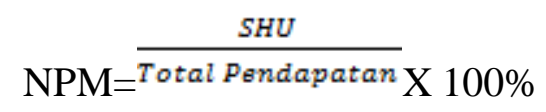

\section{b) Return On Assets(ROA)}

Return On Assets digunakan untuk mengukur tingkat pengembalian yang diperoleh koperasi atas setiap investasi yang dilakukan. Semakin tinggi ROA, semakin baik pula kinerja koperasi.

$$
\text { ROA }=\frac{\text { SHU }}{\text { Total Aset atau Aktiva }} \text { X } 100 \%
$$

\section{c) Return On Equity (ROE)}

Return On Equity digunakan untuk mengukur efisiensi penggunaan modal, dengan membandingkan SHU dengan total modal yang ada dalam koperasi. Semakin tinggi ROE, maka kinerja koperasi semakin baik.

$$
\mathrm{ROE}=\frac{\text { SHU }}{{ }^{\text {Total Modal }}} \mathrm{X} 100 \%
$$

\section{2). Perspektif Pelanggan}

\section{a) Customer Retention (CR) atau Retensi pelanggan}

Untuk mengetahui kemampuan koperasi dalam mempertahankan anggotanya dapat digunakan rumus:

$$
\mathrm{CR}=\frac{\text { Jumlah anggota lama }}{\text { Total jumlah anggota }} \mathrm{X} 100 \%
$$




\section{b) Customer Acquisition (CA) atau akuisisi pelanggan}

Akuisisi pelanggan digunakan untuk mengetahui seberapa besar kemampuan koperasi dalam menarik anggota baru.

$$
\mathrm{CA}=\stackrel{\text { Jumlah anggota baru }}{\text { Total jumlah anggota }} \mathrm{X} 100 \%
$$

\section{c) Kepuasan Pelanggan / Anggota}

Untuk mengukur tingkat kepuasan pelanggan, maka dilakukan survey kepuasan pelanggan dengan membagikan kuesioner kepada anggota koperasi. Kuesioner kepuasan pelanggan didasarkan pada atribut harga, mutu, dan waktu. Hasil dari kuesioner kemudian dianalisis dengan menggunakan:

a) Analisis Multiatribute Attitude Model (MAM), (Angel, 1994) :

$$
\mathrm{Ab}=\sum_{i=1}^{\sum_{i}} W_{i}\left|t_{i-x_{i}}\right|
$$

Keterangan:

$\mathrm{Ab}=$ sikap pelanggan secarakeseluruhan terhadap obyek

$\mathrm{Wi}=$ bobot rata-rata yang diberikan responden terhadap atribut $\mathrm{i}$

Ii = nilai ideal rata-rata pelanggan padaa tribut $\mathrm{i}$

$\mathrm{Xi} \quad=$ nilai belief rata-rata pelanggan pada atribut $\mathrm{i}$

$\mathrm{n} \quad=$ jumlah atribut

(a) Menentukan Wi dengan rumus:

$$
\text { nilai masing-masing atribut }
$$

$\mathrm{Wi}=\quad \mathrm{nilai}$ atribut $100 \%$

Tabel 1. Perolehan bobot masing-masing atribut :

\begin{tabular}{|c|c|c|}
\hline $\begin{array}{l}\text { Nomor } \\
\text { Urut }\end{array}$ & Nilai & Bobot (Wi) \\
\hline 1 & 3 & $3 / 6 \times 100 \%=50$ \\
\hline 2 & 2 & $2 / 6 \times 100 \%=33$ \\
\hline 3 & 1 & $1 / 6 \times 100 \%=17$ \\
\hline Total & 6 & 100 \\
\hline
\end{tabular}

(b) Menentukan $\mathrm{n}$ dengan cara memilih atribut yang dominan. Selanjutnya diberi nilai dari satu sampai ke-n, urutan sebelumnya diberi nilai lebih tinggi dari urutan berikutnya sebanyak $n$.

(c) Menentukan skala sikap dari kuesioner dalam bentuk skor dengan 1 sampai dengan 5 . 
Tabel 2. Urutan skala sikap :

\begin{tabular}{|c|l|c|}
\hline No & \multicolumn{1}{|c|}{ Jawaban } & $\begin{array}{c}\text { Skor } \\
\text { Sikap }\end{array}$ \\
\hline 1 & Sangat Puas / Sangat Berharap. & 5 \\
2 & Puas / Berharap. & 4 \\
3 & Ragu-Ragu. & 3 \\
4 & Tidak Puas / Tidak Berharap. & 2 \\
5 & Sangat Tidak Puas / Sangat & 1 \\
\multicolumn{2}{|l}{} \\
\hline
\end{tabular}

(d) Nilai ideal dan belief dihitung menggunakan rumus:

nilai ideal $=$ skor $\mathrm{x}$ absolute responden ideal masing-masing alternatif jawaban.

nilai belief $=$ skor $\mathrm{x}$ absolute responden belief masing-masing alternatif jawaban.

Kemudian mencari nilai belief rata-rata dan nilai ideal rata- rata:

Nilai ideal rata-rata $=\frac{\text { Total jumlah ideal }}{\text { Total absolut ideal }}$

Nilai belief rata-rata $=\frac{\text { Total jumlah belief }}{\text { Total absolut beltef }}$

(e) Masukkan data ke dalam tabel kemudian masukkan ke dalam skala Likert (Sugiyono, 1998). (sikap-1) x $100=\mathrm{X}$, sehingga diperoleh (5-1) x $100=400$ artinya skor/bobot tertinggi yaitu 5 dikurangi dengan skor/bobot terendah yaitu 1 .

Tabel 3. Skala Sikap secara keseluruhan :

\begin{tabular}{|l|ll|l|l|l|}
\multicolumn{1}{l}{ SP } & \multicolumn{2}{c}{ P } & \multicolumn{2}{c}{ RR } & \multicolumn{2}{c|}{ TP } & \multicolumn{2}{c|}{ STP } \\
\hline & & & & & \\
\hline 0 & 80 & 160 & 240 & 320 & 400
\end{tabular}

Keterangan:

$$
\begin{array}{ll}
0-80 & =\text { Sangat Puas } \\
80-160 & =\text { Puas } \\
160-240 & =\text { Ragu-Ragu } \\
240-320 & =\text { TidakPuas } \\
320-400 & =\text { Sangat Tidak Puas }
\end{array}
$$

Hasil perhitungan skala sikap secara keseluruhan dapat diartikan jika skala semakin kecil atau mendekati nol, maka sikap anggota secara keseluruhan semakin baik. Hal ini dapat dikatakan bahwa anggota merasa puas terhadap produk dan layanan jasa yang diberikan oleh Koperasi. Jika skala semakin ke kanan maka sikap anggota secara keseluruhan relatif tidak baik / negatif, hal ini dapat dikatakan bahwa pelanggan merasa tidak puas terhadap produk dan layanan jasa yang diberikan oleh koperasi. 
f) Analisis Prioritas Kepentingan Analisis ini digunakan untuk mengetahui atribut-atribut yang paling menentukan sikap anggota dalam menggunakan jasa yang diberikan oleh koperasi. Dalam kuesioner, jawaban responden diberi peringkat sebagai berikut:

Tabel 4. Prioritas Kepentingan.

\begin{tabular}{|c|c|}
\hline Peringkat & Bobot \\
\hline 1 & 3 \\
\hline 2 & 2 \\
\hline 3 & 1 \\
\hline
\end{tabular}

Jawaban responden dari setiap atribut dikalikan dengan bobot yang diberikan dari setiap atribut kemudian dijumlahkan. Hasil dari perkalian setiap atribut menentukan ukuran - ukuran kepentingan. Hasil yang paling banyak merupakan atribut yang menjadi prioritas utama dalam menggunakan produk / jasa.

\section{Persepektif Proses Bisnis Internal}

Untuk mengukur tingkat kepuasan pelanggan / anggota, maka dilakukan survey kepuasan anggota dengan membagikan kuesioner kepada anggota koperasi. Kuesioner kepuasan anggota didasarkan pada atribut Inovasi, Proses Opreasi dan Layanan -Purna Jual. Hasil dari kuesioner kemudian dianalisis dengan menggunakan:

Analisis Multiatribute Attitude Model (MAM).

\section{Perspektif Pertumbuhan dan Pembelajaran}

Untuk mengukur tingkat kepuasan karyawan, pengurus dan pengawas maka dilakukan survey kepuasan karyawan, pengurus dan pengawas dengan membagikan kuesioner kepada mereka. Kuesioner kepuasan karyawan, pengurus dan pengawas didasarkan pada atribut Kepuasan Karyawan, Kepuasan Pengurus dan Kepuasan Pengawas. Hasil dari kuesioner kemudian dianalisis dengan menggunakan:

Analisis Multiatribute Attitude Model (MAM).

\section{Penentuan baik dan buruknya kinerja KopKar Untag Sby.}

Standar untuk melihat baik dan buruknya kinerja KopKar Untag Sby adalah dengan menentukan kriteria pada masing-masin perspektif. Kriteria tersebut kemudian dibandingkan dengan keadaan koperasi yang sebenarnya. Jika keadaan koperasi sesuai dengan kriteria yang ada pada Balanced Scorecard, maka perspektif tersebut dikatakan baik. Sebaliknya, apabila keadaan koperasi tidak sesuai dengan kriteria yang telah ditetapkan maka perspektif tersebut dikatakan buruk atau tidak baik.

Untuk mengetahui kriteria baik dan buruk kinerja koperasi secara keseluruhan digunakan penilaian yang dikembangkan oleh Carolina (Carolina, 2011) sebagai berikut:

1) Kinerja sangat baik = jika 4 perspektif dinilai baik

2) Kinerja baik = jika 3 perspektif dinilai baik

3) Kinerja kurang baik $=$ jika 2 perspektif dinilai baik

4) Kinerja tidak baik = jika 1 perspektif dinilai baik 


\section{Hasil dan Pembahasan.}

\section{Pengujian Instrumen}

Pengujian validitas dan reliabilitas dilakukan untuk menguji setiap instrument pada kuesioner yang telah dibagikan. Dari 617 anggota KopKar telah dibagikan kuesioner kepada sample sejumlah 86 responden anggota.

Dengan SPSS 22 dengan taraf signifikan 5\%, hasil uji validitas anggota diketahui bahwa keseluruhan dari butir pertanyaan pada kuesioner kepuasan anggota adalah valid dengan rhitung lebih besar dari $\mathrm{r}$ tabel. Dimana $\mathrm{r}$ tabel $=0.2521$ dengan $\mathrm{r}$ hitung paling rendah 0,3734.

Demikian pula untuk uji Reliabilitasnya diketahui bahwa alpha hitung belief dan ideal pada kuesioner anggota lebih besar dari table dengan taraf signifikan 5\% sehingga kuesioner tersebut dapat dikatakan reliabel. Dimana $\mathrm{r}$ tabel $=0.2521$ dengan $\mathrm{r}$ hitung paling rendah 0,8188 .

\section{Hasil : Kinerja KopKar berdasarkan Perspektif Balanced Scorecard.}

\section{Perspektif Keuangan}

Untuk mengukur kinerja perspektif keuangan KopKar Untag Sby, dilakukan dengan menganalisa rasio NPM, ROA, dan ROEnya.

Secara keseluruhan ketiga rasio tersebut dapat dilihat pada tabel sebagai berikut:

Tabel 5. Net Profit Margin (NPM), Return On Activa (ROA) dan Return On Equity (ROE) KopKarUntag Sby Tahun 2015 - 2019.

\begin{tabular}{|llcr|}
\hline & \multicolumn{3}{c|}{ Rasio } \\
\hline Tahun & NPM & ROA & ROE \\
\hline 2015 & 13,63 & 5,56 & 9,71 \\
\hline 2016 & 16,39 & 6,39 & 8,69 \\
\hline 2017 & 26,77 & 9,68 & 10,22 \\
\hline 2018 & 29,11 & 8,60 & 8,85 \\
\hline 2019 & 27,75 & 7,04 & 7,30 \\
\hline
\end{tabular}

Dari table diatas menunjukkan Rasio NPM naik dan turun di 2019, Artinya dari rasio NPM ini perspektif keuangan KopKar masih cukup baik.

Dari ROA, terlihat bahwa ROA naik turun juga, hal ini karena tidak sebandingnya SHU dengan total aktiva yang dikeluarkan oleh KopKar. KopKar setiap tahunnya mengeluarkan aktiva yang besar dan terus meningkat setiap tahunnya tetapi profit yang diperoleh KopKar kurang.

Dari kenaikan dan penurunan ROE pada tahun 2015 - 2019 sebesar -1,02\%, +1,53, 1,37, dan -1,55\% yang disebabkan oleh kenaikan modal KopKar dengan seiring naiknya laba bersih. Tetapi Peningkatan modal KopKar setiap tahunnya tidak sebanding dengan laba yang diperoleh KopKar.

Sehingga dari semua rasio yaitu NPM, ROA dan ROE dapat disimpulkan bahwa profitabilitas KopKar Untag Sby relative masih baik.

\section{Perspektif Pelanggan ( Anggota ).}

Untuk mengetahui kinerja KopKar Untag Sby dari segi perspektif pelanggan, dilakukan analisis berikut: 


\section{a). Retensi Anggota.}

Retensi Anggota merupakan kemampuan Koperasi dalam mempertahankan anggotanya. retensi anggota KopKar Untag Sby dari tahun 2015, tahun 2016 mengalami penurunan. Pada tahun 2017 naik lagi namun masih dibawah tahun 2015, dan turun lagi pada tahun 2018. Ditahun 2019 ternyata juga turun lagi. Dari jumlah anggota lama terdapat anggota yang keluar yaitu di tahun 2015 sebanyak 7 orang, tahun 2016 sejumlah 17 orang, tahun 2017 sejumlah 12 orang, tahun 2018 sejumlah 17 orang, dan tahun 201927 orang. Hal ini menunjukkan KopKar Untag Sby tidak dapat mempertahankan anggotanya karena terjadi peningkatan anggota yang keluar (pensiun).

\section{b). Akuisisi Anggota}

Akuisisi pelanggan menunjukkan seberapa besar kemampuan perusahaan dalam menarik anggota baru. Akuisisi pelanggan KopKar Untag Sby mengalami peningkatan selama tahun 2015 - 2017. Namun ditahun tahun selanjutnya 2018 dan 2019 terjadi penurunan drastis. Hal ini berarti bahwa KopKarUntag Sby tidak dapat mengendalikan dan meningkatkan jumlah anggotanya. Hal ini bisa dimaklumi karena anggota KopKar murni hanya dari karyawan UntagSurabaya.

\section{Kepuasan Anggota}

Untuk mengetahui tingkat kepuasan anggota, maka hasil kuesioner dianalisis menggunakan :

a) Multiatributte Attitude Models (MAM), didapatkan :

$$
\begin{aligned}
\mathrm{Ab} & =\sum_{i=1}^{n} W_{i}\left|t_{i-x_{i}}\right| \\
& =26,31
\end{aligned}
$$

Hasil di atas menunjukkan bahwa nilai sikap anggota secara keseluruhan terhadap atribut harga, mutu, dan waktu adalah 26,31. Ini berarti anggota merasa sangat puas terhadap produk atau jasa KopKar Untag Sby. Jadi dapat disimpulkan pelayanan yang diberikan kepada anggota sudah baik.

b). Analisis Prioritas Kepentingan

Dari perhitungan, atribut yang dianggap paling penting oleh anggota adalah mutu dengan total nilai 154 , prioritas kedua adalah atribut harga sebesar 131 dan prioritas ketiga adalah waktu dengan nilai 128 .

\section{Perspektif Proses Bisnis Internal.}

Pengukuran kinerja perspektif proses bisnis internal dilakukan pada 3 Atribut yaitu : Inovasi, Proses Operasi dan Purna Jual (layanan). Quesioner diberikan kepada Anggota KopKar, dan dianalisis dengan Multy attribute Attitude Model. 
INOBIS: Jurnal Inovasi Bisnis dan Manajemen Indonesia

Volume 04, Nomor 01, Desember 2020

Mochammad Singgih, Djoko Sulisyono

a). Hasi perhitungan sikap anggota dengan Multiatributte Attitude Models didapatkan :

$$
\begin{aligned}
\mathrm{Ab} & =\sum_{i=1}^{n} W_{i}\left|I_{i-x_{i}}\right| \\
& =169.08
\end{aligned}
$$

Hasil di atas menunjukkan bahwa nilai sikap anggota terhadap atribut / kinerja Inovasi, Proses Operasi dan Layanan Purna Jual secara keseluruhan adalah sebesar 169,08. Ini berarti anggota merasa ragu terhadap kinerja Inovasi, Proses Operasi dan Layanan Purna Jual dari KopKar Untag Sby. Jadi dapat disimpulkan bahwa anggota merasa ragu / kurang puas atas kinerja dari Perspektif Proses Bisnis Internal KopKar Untag Sby.

b), Analisis Prioritas Kepentingan

Dari hasil analisis prioritas kepentingan, atribut yang dianggap paling penting oleh anggota adalah kinerja Inovasi dengan total nilai 150, pada prioritas kedua adalah kinerja Proses Operasi sebesar 133 dan prioritas ketiga adalah Layanan Purna Jual dengan nilai 130. Jadi dapat disimpulkan bahwa kemampuan kinerja KopKar Untag Sby dalam Proses Bisnis Internal kurang baik. Hal ini ditunjukkan dengan kemampuan dalam proses inovasi, operasi dan layanan purna jual yang oleh anggota dinilai meragukan.

\section{Perspektif Pertumbuhan dan Pembelajaran}

a) Kepuasan karyawan

Perhitungan sikap Karyawan dengan Multiatributte Attitude Models didapatkan :

$$
\begin{aligned}
\mathrm{Ab} & ={ }^{\sum_{i=1}^{n}} W_{i}\left|I_{i-x_{i}}\right| \\
& =119
\end{aligned}
$$

Hasil di atas menunjukkan bahwa sikap karyawan terhadap kinerja komunikasi, penghargaan, dan dukungan KopKar Untag Sby secara rata rata adalah puas.

Jadi dapat disimpulkan bahwa kepuasan karyawan terhadap KopKar Untag Sby cukup baik. (Namun perlu perhatian karena sudah mendekati posisi ragu ragu, dan factor utamanya bisa dilihat adalah dari penghargaan yaitu Gaji,

Analisis Prioritas Kepentingan

Dari hasil perhitungan, urutan atribut yang paling dianggap penting oleh karyawan adalah komunikasi dengan total nilai 6 , pada prioritas kedua adalah atribut penghargaan sebesar 4 dan prioritas ketiga adalah dukungan dengan nilai 3. Tampaknya karena komunikasi antara pengurus dengan karyawan cukup baik, sehingga penghargaan belum begitu masalah.

\section{b). Kepuasan Pengurus}

Perhitungan sikap Pengurus dengan Multiatributte Attitude Models didapatkan:

$$
\begin{aligned}
\mathrm{Ab} & =\sum_{i=1}^{n} W_{i}\left|I_{i-x_{i}}\right| \\
& =53,11
\end{aligned}
$$

Dari hasil di atas dapat diketahui bahwa sikap pengurus terhadap kemampuan karyawan, kemampuan sistem informasi, motivasi, pemberian, dan pembatasan wewenang KopKar adalah 
sangat puas.

Jadi dapat disimpulkan bahwa kepuasan pengurus terhadap kinerja KopKar Untag Sby adalah sangat baik.

\section{2). Analisis Prioritas Kepentingan}

Dari perhutungan prioritas kepentingan atribut yang dianggap paling penting oleh pengurus adalah kemampuan karyawan dengan total nilai 6, pada prioritas kedua adalah kemampuan system informasi sebesar 4, dan prioritas ketiga atribut motivasi, pemberian, dan pembatasan wewenang dengan nilai 2 .

\section{c). Retensi Karyawan}

Retensi karyawan KopKar Untag Sby ditunjukan dengan jumlah karyawan yang keluar dan masuk. Dari data tahun 2015 - 2018 tidak ada karyawan yang keluar ataupun masuk. Hal ini menunjukkan bahwa KopKar Untag Sby selama 2015 - 2018 dapat mempertahankan karyawannya. Tetapi di tahun 2019 ada 3 karyawan tidak aktif lagi di KopKar, dan ada masuk 2 karyawan baru untuk toko (Bursa). Dari data diatas dapat disimpulkan Retensi Karyawan KopKar kurang baik. Namun dari kepuasan karyawan, karyawan puas dengan kineja KopKar.

\section{d). Kepuasan Pengawas.}

1). Perhitungan sikap Pengawas dihitung dengan menggunakan Multiatributte Attitude Models didapatkan :

$$
\begin{aligned}
\mathrm{Ab} & =\sum_{i=1}^{n} W_{i}\left|I_{i-x_{i}}\right| \\
& =152,72
\end{aligned}
$$

Dari hasil di atas dapat diketahui bahwa sikap pengawas terhadap atribut Kinerja Perencanaan, Organisasi, dan Operasional dari KopKar Untag sby adalah puas namun hampir ragu ragu.

Jadi dapat disimpulkan bahwa kepuasan pengawas terhadap kinerja KopKar Untag Sby cukup baik.

\section{2). Analisis Prioritas Kepentingan}

Dari perhitungan prioritas kepentingan, atribut yang dianggap paling penting oleh pengawas koperasi adalah Perencanaan dengan total nilai 3, pada prioritas kedua adalah atribut Organisasi sebesar 2 dan prioritas ketiga adalah Operasional dengan nilai 1.

\section{Pembahasan}

\section{Perspektif Keuangan}

Dari hasil analisis menunjukkan, perspektif keuangan KopKar Untag Sby menunjukkan hasil yang kurang menggembirakan alias kurang baik. Hal ini ditunjukkan dari rasio Net Profit Margin, Return On Assets, dan Return On Equit yang mengalami penurunan berturut turut pada 2 tahun terakhir yaitu 2018 - 2019. Selama 5 tahun pengamatan yaitu 2015 - 2019 besaran SHU setiap tahun selalu meningkat, namun peningkatannya tidak sebanding dengan peningkatan pendapatan, kekayaan dan assetnya. 


\section{Perspektif Pelanggan}

Pada perspektif pelanggan ini digunakan tiga tolok ukur yaitu retensi anggota, akuisisi anggota, dan kepuasan anggota. Hasil penelitian menunjukkan, pada retensi anggota mengalami naik turun tetapi penurunan yang terbesar ada pada tahun akhir yatu 2019. Dan untuk Akuisisi anggota juga naik turun. Dari tahun 215 naik berurutan hingga 2017, namun setelahnya yaitu tahun 2018 dan 2019 makin menurun. Dan untuk hasil kepuasan anggota adalah secara umum anggota merasa sangat puas yaitu pada nilai MAM sebesar 26,31. Jadi Kinerja KopKar Untag Sby pada perspektif pelanggan / anggota dapat dikatakan cukup baik, meski 2 indikator yaitu retensi anggota dan akuisisi anggota kurang baik (untuk hal ini memang tidak bisa dikendalikan oleh KopKar sendiri), namun kepuasan pelanggan dalam keadaan baik.

\section{Perspektif Proses Bisnis Internal}

Pada perspektif proses bisnis internal ini digunakan indikator inovasi, proses operasi, dan layanan purna jual. Hasil penelitian menunjukkan kondisi bahwa sikap anggota terhadap atribut / kinerja Inovasi, Proses Operasi dan Layanan Purna Jual secara keseluruhan pada nilai MAM terletak pada posisi 169,08. Hal ini berarti bahwa anggota merasa ragu ragu terhadap kinerja Inovasi, Proses Operasi dan Layanan Purna Jual dari KopKar Untag Sby. Jadi dapat disimpulkan bahwa kinerja dari Perspektif Proses Bisnis Internal meragukan atau anggota tidak puas dan factor utamanya inovasi yang masih lemah. Inovasi bisa meliputi pengembangan produk dan jasa, kualitas produk dan jasa, investasi baru dan lainya.

\section{Perspektif Pertumbuhan dan Pembelajaran}

Dan pada Perspektif pertumbuhan dan pembelajaran menunjukkan hasil yang relative cukup baik, namun harus waspada. Karyawan merasa puas namun perlu waspada dengan nilai MAM 119. Untuk pengurus merasa sudah sangat puas dengan kinerja KopKar, hal ini ditunjukkan dengan hasil analisis MAM pada pada posisi 53,11.

Dan pada retensi karyawan menunjukkan bahwa KopKar kurang dapat mempertahankan karyawannya.

Sementara untuk kepuasan pengawas menunjukkan bahwa sikap pengawas terhadap atribut Kinerja Perencanaan, Organisasi, dan Operasional dari KopKar Untag sby adalah puas namun hampir ragu ragu dengan nilai MAM 152,72.

Jadi secara keseluruhan kinerja dari perspektif pertumbuhan dan pembelaajaran relative masih cukup baik, namun harus sudah diwaspadai dan ditingkatkan untuk perbaikan .

\section{Kesimpulan}

Dari penelitian ini dapat disimpulkan bahwa, keempat kinerja Balanced Scorecard KopKar Untag Surabaya untuk tahun kinerja 2019 / 2020 adalah Sbb :

\section{Perspektif Keuangan}

Dari semua Analisa rasio yaitu NPM, ROA dan ROE dapat disimpulkan bahwa profitabilitas KopKar Untag Sby masih kurang atau kurang baik. 


\section{Perspektif Pelanggan / Anggota}

Untuk retensi anggota, jumlah keseluruhan anggota mengalami naik turun. Demikian pula untuk Akuisisi anggota juga naik turun.

Untuk Kepuasan Anggota, secara umum anggota merasa sangat puas atas kinerja KopKar yaitu dengan nilai MAM sebesar 26,31. Jadi Kinerja KopKar Untag Sby untuk perspektif pelanggan / anggota dapat dikatakan cukup baik.

\section{Perspektif Proses Bisnis Internal.}

Sikap anggota terhadap kinerja perspektif proses bisnis internal KopKar adalah ragu ragu dengan nilai MAM 169,08. Hal ini berarti bahwa anggota merasa ragu ragu terhadap kinerja Inovasi, Proses Operasi dan Layanan Purna Jual KopKar Untag Sby. Jadi dapat disimpulkan bahwa dari kinerja Perspektif Proses Bisnis Internal, anggota merasa ragu ragu (kurang puas) dan factor utamanya adalah inovasi yang lemah.

\section{Perspektif Pertumbuhan dan pembelajaran.}

Pada perspektif ini Karyawan merasa puas dengan nilai MAM 119, namun perlu waspada. Untuk pengurus merasa sudah sangat puas dengan kinerja KopKar dengan nilai MAM berada pada posisi 53,11. Untuk retensi karyawan menunjukkan bahwa KopKar kurang dapat mempertahankan karyawannya dan untuk kepuasan pengawas menunjukkan bahwa sikap pengawas terhadap Kinerja Perencanaan, Organisasi, dan Operasional dari KopKar Untag sby adalah puas namun hampir ragu ragu dengan nilai MAM 152,72. Jadi kinerja perspektif pertumbuhan dan pembelaajaran bisa dikatakan relative baik, namun harus sudah diwaspadai dan ditingkatkan untuk perbaikan.

Dari keempat perspektif Balanced Scorecard hanya 1 perspektif yaitu Proses bisnis internal yang menunjukkan kinerja kurang baik, dan 3 perspektif yang lainnya baik.

Sehingga dapat disimpulkan bahwa kinerja KopKar Untag Sby secara keseluruhan diukur dengan metode Balanced Scorecard menunjukkan kenerja yang masih baik, namun perlu perbaikan aktif.

Dan Rekomendasi langkah-langkah strategis bagi KopKar Untag Sby untuk memperbaiki dan meningkatkan kinerja di masa datang adalah :

a. Koperasi harus lebih aktif / agresif dan berorientasi bisnis, sehingga harus dikelola dengan prinsip prinsip bisnis, yaitu gencar berinovasi dan mencari peluang, gencar dalam pemasaran, menjaga kualitas dan lain lain.

b. Langkah pertama perbaikan kinerja karyawan sebagai ujung tombak KopKar keluar dan kedalam, untuk itu perlu peningkatan penghargaan terhadap karyawan.

c. Mengajak semua anggota kompak tulus mengembangkan KopKar.

d. Dibuat perencanaan jangka pendek dan panjang yang terukur sesuai visi misi yang update.

e. Lakukan Kerjasama dengan pihak lain yang benar benar mampu meningkatkan kinerja dan kemajuan KopKar kedepan.

f. Satukan Tekad gerak maju Bersama semua komponen KopKar yaitu Pengurus, Manajer dan karyawan, Pengawas dan Anggota.

g. Perlu meninjau Kembali ketentuan dan aturan keanggotaan para pensiunan, karena akan memberikan jaminan pada mereka.

h. Mengajukan tambahan tempat / ruang yang lebih luas. 
INOBIS: Jurnal Inovasi Bisnis dan Manajemen Indonesia

Volume 04, Nomor 01, Desember 2020

Mochammad Singgih, Djoko Sulisyono

\section{Referensi.}

Abdul Halim, dkk (2009). Sistem Pengendalian Manajemen. Edisi Revisi. Cetakan ketiga. Yogyakarta: Sekolah Tinggi llmu Manajemen YKPN.

Butler, Letza, Neale (1997), Linking The Balanced Scorecard to Strategy, Long Range Planning, Vol 30, pages 242-253, 153.

Gaspers, V., (2003). Sistem Manajemen Kinerja Terintegrasi, Balanced Scorecard dengan Six Sigma Untuk Organisasi Bisnis dan Pemerintah. PT, Gramedia Pustaka Utama, Jakarta.

Kaplan, Robert S, Norton. D.P. (1992). The Balance Scorecard - Measures That Drive Performance / Robert S. Kaplan, David P. Norton. Tt - Harvard Business Reviev TA -, 70(1), 71. https:// doi.org/ 00178012

Kaplan, Robert S, Norton. D. P (2000). Balance Scorecard : Menerapkan Strategi Menjadi Aksi, Penerbit Eriangga. Jakarta.

Partomo. T.S, 2009, Ekonomi Koperasi, Ghalia Indonesia, Jakarta

Sujarweni. V. W, 2015, Akuntansi Manajemen : Teori dan Aplikasi, Pustaka Baru Press, Yogyakarta. 